particles in excess of $5 \mu$; but the filtered air supplied to operating theatres is additionally passed through bacteriological filters. In the radioactive experimental animal room provision is made for air extract from each individual metabolism cage in order to avoid cross-contamination by ${ }^{14} \mathrm{CO}_{2}$.

All the widely used services are brought into the building in a central plant room and thence distributed by commodious vertical ducts, to which there is ready access at all floor-levels, at each of the four corners of the building. Because of the known vagaries of centralized vacuum systems due to extreme fluctuations in demand and the sensitivity of experimental apparatus to relatively minor fluctuations, vacuum is generated locally as required throughout the new research laboratories.

As annexes to the main pharmacology laboratory there are laboratories for isolated organ bath screening procedures and for whole-animal experimental procedures. There is also a constant-temperature laboratory for experimental procedures in which temperature changes make an appreciable contribution to total variances. A further laboratory is both sound-proofed and electrically screened. Thus, it may be used either for experimental animal behavioural investigation or for electro-physiological experimentation.

The radioactive isotope laboratory, for reasons of safe and orderly use by appropriately trained scientific staff, is under the supervision of the senior biochemist, since his department are main users for metabolism and detoxification investigations. The electrically screened counting room is as remote as possible from the baryta-concrete protected store and 'hot' laboratory. Expert advice has been found to be divided in regard to electrically screening the counting room. Because of the low counts common in biological work, the uncertain control of interference near the site for the future, the relatively low cost and freedom from dislocation and hazard by building-in screening during construction rather than later, the decision was taken to build in screens during construction. Bearing in mind the rapid advances in the use of radioactive isotopes in biological research, the fact that the radioactive isotope laboratory is intended to provide a service to the group with its manifold interests, and the estimate of a useful 25-year life for the block, over-provision in respect of space and safety facilities has been deliberately made relative to anticipated needs in the near future throughout planning and construction.

Already existing laboratories support the work of the new Biological Research Laboratories. These include: chemical analysis; micro-elemental analysis with flame photometry; spectroscopy (ultra-violet and infra-red); chromatography (vapour phase, thin layer, paper electrophoresis, etc.). All research workers draw strength and confidence from the well-established Statistical Department in respect of experimental planning and analysis. After the 1942 bombing, a complete library and information service has had to be re-assembled and this has been functioning efficiently, especially during the past decade or so.

Messrs. Reckitt and Sons, Ltd., one of the six main operating companies of the Reckitt and Colman Holdings Limited Group, are well established in the pharmaceutical field with 'Dettol', the antiseptic developed in their Bacteriological Research Laboratories and introduced to the medical profession in 1932; with 'Disprin'-the first stable, soluble preparation of aspirin introduced at the London Medical Exhibition in 1948 as the first-fruit of post-war research, and the therapeutically related 'Codis' and 'Cafdis'; with the stable non-nauseating antacid preparation, 'Alcin'. Through the Joint Research Association with J. F. Macfarlan and Co., Ltd. (for a review of the historical setting in which this Company was founded at the end of the eighteenth century see: "William Gregory, M.D., F.C.S.: 1803-1858", by G. Colman Green, Nature, $157,465: 1946)$, there is the promise of fruition of scientific research in novel ways in the potent analgesic field (see K. W. Bentley and D. G. Hardy (Proc. Chem. Soc., 220; July 1963), as mentioned earlier in this article. With the new Biological Research Laboratories now available it is hoped that the Company's repute and activities in the pharmaceutical field throughout the world will be both consolidated and extended.

G. Colman Green

\title{
THE CASACCIA CENTRE FOR NUCLEAR STUDIES
}

$\mathrm{T}$ HE Casaccia Centre for Nuclear Studies, of the Comitato Nazionale per l'Energia Nucleare, Rome, comprises a complex of facilities and laboratories concerned with research in the various sectors connected with the production and uses of nuclear energy. The Centre occupies an area of about 160 acres: it is divided into nine areas, each assigned to a specific activity. The subdivision into areas was made with regard to the possibilities of future expansion of the Centre, space being allowed for further developments.

The $R C-1$ reactor. The $R C-1$ (Reattore Casaccia-1) reactor, the maximum power of which is of $100 \mathrm{~kW}$, is the Centre's major installation.

The reactor core, surrounded by a graphite reflector, is a complex of homogeneous fuel-moderator elements made up by a ternary alloy of 20 per cent enriched uranium $\left({ }^{235} \mathrm{U}\right)$ and zirconium hydride. The reactor is contained in a pit about $19 \mathrm{ft}$. deep filled with demineralized water, which performs a two-fold function as shield and moderator. The neutron moderation function is performed also by the zircon hydride. A concrete tank located near the main reactor pit is used for experiments on the attenuation of neutrons and $\gamma$-rays. 'The reactor's experimental equipment also comprises: a thermal column, four horizontal and one vertical irradiation channels, a pneumatic pipe for the fast transfer of the various short-lived isotopes and a revolving rack which makes it possible to irradiate forty samples simultaneously. In the course of the modification work a second vertical channel was installed in the portion of the thermal column projecting inside the pit.

Applied Nuclear Physics Laboratory. The research activity of the applied nuclear physies laboratory is conducted along two lines: experimental and theoretical.

For experimental research, the laboratory uses the $R C-1$ reactor and the Van de Graaff pulsed accelerator. Among theoretical research projects of particular interest are investigations on the slowing and thermalization of neutrons in organic moderators. These investigations fit into the framework of one of CNEN's major objectives, that is, the all-Italian development and construction of an organic-moderated reactor, which will provide information for the subsequent development of power reactors of this kind (Pro).

Reactor Engineering and Servomechanisms Laboratory. This laboratory is concerned with all problems connected with the designing and construction of nuclear reactors or installations.

Among its projects special mention should be made of the nuclear plant simulator, an electronic manipulator for radioactive premises, one set of the standard equipment for the control of nuclear reactors (SCIN Project), an experimental moderated and organic zero-power reactor and a set of experimental circuits built for the testing of 
mechanical components in an organic fluid for experiments on thermal and fuido-dynamic exchange of advanceddesign fuel elements.

The 'Mascot 1' manipulator (servo-controllod transistorized manipulator) consists of two stations, 'Master' and 'Slave' (interconnected exclusively by means of electric cables). The formor serves as the operator's control station, while the latter is a true robot which can operate in contaminated spaces.

The Rospo reactor (experimontal zero-powor organic reactor), which is schoduled to become critical before the ond of 1963 , fits into the framework of the research conducted in support of the designing of the Pro reactor. It is designed to operate up to a tomperature of $662^{\circ} \mathrm{F}$.

Physics and Reactor Calculus Laboralory. The laboratory's work programme is centred on two major projects at prosent boing implemented by CNFN.

As regards the organic reactors programme (Pro), investigations are now in progress for tho optimization and noutronie design of the subsequent uranium-oxide cores; these investigations will be supported by critical experiments in tho Rospo reactor. With regard to tho utilization of the uranium-thorium eycle, thoorotical investigations are in progress for both the water reactor and the organic-moderated reactors.

The electronics laboratory dovelops, among other things, equipment for a wide variety of measurements: \& radiation 'dose' counter for general use in experiments with nuclear machines; a portablo soil density and moisturo meter; an ionization vacuum meter; a detector of leaks in vacuum systems; an ambient radioactivity control systom; a low neutron flux measurement channel for the control of reactors in the initial operating stage; neutron detectors and apparatus for measurement and calculus using analogue and digital tochniques.

Hot cells. The hot operations laboratory, already in action, is located in the area where the technological metallurgical laboratory will be installed and comprises a group of five hot colls aligned and divided into three sections. In those cells are porformed various chemical and metallurgical investigations on irradiated materials with activity not higher than 1,000 curies. The oells are served by an overhead travelling crane. Entrance to the cells is through three electrically-controlled doors in the cell-loading area.

Central Laboratories of the Geology-Mining Division. These laboratories have brought together at the Casaccia Centre for Nuclear Studies several research units. At present, these laboratories, which form a modern organization for prospecting and for the solution of basic problems, are made up by mobile teams equipped with truck-mountod laboratories and by stationary analysis laboratories. Advanced techniques have been developed and fully tried out; this is true in particular of methods for geochomical and mineralogical prospecting, which constitute the most advanced sector of the geologicalmining investigations with respect to the exploration for various elements of nueleur interest.

Agricultural Applications Laboratory. This laboratory is responsible for the promotion of the development of nueloar energy applications in agriculture. Among the methods offered by nuclear scionces, it investigatos those which can be used towards the solution of the problems of vogetables and animal production and, through experiments conducted in co-oporation with other Italian and foreign research organizations, evaluates the possibilities and opportunities for the application of such methods.

The laboratory eomprises throe seientific soctions (genetics and radiobiology, chemistry and radioisotopes, irradiation techniques) and operates the $\gamma$-field as the principal irradiation facility.

The $\gamma$-field. The more complex system existing in the biological area is the $\gamma$-field, established to examine the effects of the $\gamma$-irradiation on plants; it is the first of this kind installed in the Euratom countries.

\section{THE FLORA OF TROPICAL AFRICA}

T HE fifth plonary mooting of the Association pour l'Fudu Taxonomique de la Flore d'Afrique Tropicale whs held in Italy during September 9-14.

The conferenco oponed on September 9 at the Istituto Botanico 'Hanbury', Genos, with an address of wolcomo by the Rector of the University. An outline of the history of the Institute was given by the present director, Prof. R. IS. G. Pichi-Sermolli, who was secretary of the Associstion and convenor of the conference. The name 'Hanbury' was given to the Institute in 1892 in recognition of a benefaction made by Sir Thomas Hanbury, founder of tho famous La Mortola Gardens and donor of Wisley Gardens to the Royal Hortieultural Society. Dr. A. W. Exell thanked the Reetor on behalf of the 45 delegates reprosenting some 19 different countries. He recalled that there had been much political change in Africa since the fourth meetirg held in Portugal in 1960, and, although botanist: working on A,frican plants wished to have no part in African politics, such changes inevitably affected their work in various ways. Dr. Exoll was pleased to seo sovoral Afrienn delegates present, and ho hoped that the now Africen States would join the older countries as partners in furthoring botanical research. It was important that A,frien nationals should persuado their own Governments of the importance of the work on their flora and of the necessity of much of the taxonomy being earried out in Europe, for it cannot bo done in Africa itself. In this connexion, Dr. Exell mentioned a paper entitled "The Value of Flores to Undordovolopod Countries" by Y. P. M. Brenan, publishod recently in Impact $(3,121 ; 1963)$.
The session devoted to reports on the progress of African Floras proved that activity on the taxonomy of tropical Africen plants remains undiminished in intensity. The first parts of new Floras, such as Flore du Gabon and the mainly extra-tropical F'lora of Southern Africa, have appeared since the last conference. Other reports dealt with the progress of the Flora of Tropical E'ast Africa, Flore du Congo du Rwanda et du Burundi, Conspectus Florae Angolensis, Flora Zambesiaca, Flore de Madagascar et des Comores, Enumeratio Plantarum Aethiopiae Spermatophyta and tho Adumbratio F'lorae Aethiopicae; tho inminent publication of Volume 2 of the Flora of West Tropical Africa and the first part of F'lore du Cameroun; and tho proparation of tho Flora of South-West Africa.

A full day was devoted to the principal theme of the conference: the phytogeographical elements in Africa and the rolationship between the flora of tropical $\Lambda$ frica and that of other continents. Prof. J. Léonard and Prof. C. Evrard analysed parts of the Congo flora, while $\mathrm{F}$. N. Hoppor discused his analysis of tho Wost African dicotyledons and the relation of the flora to that of Asia and America. Dr. A. Wild produced what he considered to bo additional evidence for the $\Lambda$ friceMadagascar-India-Ceylon land-bridge theory, and an account of the elements in the afroalpine flora was pre. sented by Dr. O. Hedberg, well known for his work on African mountain plants. J. P.M. Brenan summarized an interesting snalysis of the geographical relationships of all the genora of Leguminosas occurring in tropical 